Article

\title{
New Polyenes from the Marine-Derived Fungus Talaromyces cyanescens with Anti-Neuroinflammatory and Cytotoxic Activities
}

\author{
Hee Jae Shin ${ }^{1,2, *}$, Cao Van Anh ${ }^{1,2}$, Duk-Yeon Cho ${ }^{3}$, Dong-Kug Choi ${ }^{3}{ }^{\circledR}$, Jong Soon Kang ${ }^{4}$, \\ Phan Thi Hoai Trinh ${ }^{5}{ }^{\oplus}$, Byeoung-Kyu Choi ${ }^{1}$ and Hwa-Sun Lee ${ }^{1}$
}

1 Marine Natural Products Chemistry Laboratory, Korea Institute of Ocean Science and Technology, 385 Haeyang-ro, Yeongdo-gu, Busan 49111, Korea; caovananh@kiost.ac.kr (C.V.A.); choibk4404@kiost.ac.kr (B.-K.C.); hwasunlee@kiost.ac.kr (H.-S.L.)

2 Department of Marine Biotechnology, University of Science and Technology (UST), 217 Gajungro, Yuseong-gu, Daejeon 34113, Korea

3 Department of Applied Life Science, Graduate school, BK21 Program, Konkuk University, Chungju 27478, Korea; whejrdus10@kku.ac.kr (D.-Y.C.); choidk@kku.ac.kr (D.-K.C.)

4 Laboratory Animal Resource Center, Korea Research Institute of Bioscience and Biotechnology, 30 Yeongudanjiro, Cheongju 28116, Korea; kanjon@kribb.re.kr

5 Department of Marine Biotechnology, Nhatrang Institute of Technology Research and Application, Vietnam Academy of Science and Technology, 02 Hung Vuong, Nha Trang 650000, Vietnam; phanhoaitrinh84@gmail.com

* Correspondence: shinhj@kiost.ac.kr; Tel.: +82-51-664-3341; Fax: +82-51-664-3340

Citation: Shin, H.J.; Anh, C.V.; Cho, D.-Y.; Choi, D.-K.; Kang, J.S.; Trinh, P.T.H.; Choi, B.-K.; Lee, H.-S. New Polyenes from the Marine-Derived Fungus Talaromyces cyanescens with Anti-Neuroinflammatory and Cytotoxic Activities. Molecules 2021, 26, 836. https://doi.org/10.3390/ molecules26040836

Academic Editor: Karel Šmejkal

Received: 24 December 2020

Accepted: 2 February 2021

Published: 5 February 2021

Publisher's Note: MDPI stays neutral with regard to jurisdictional claims in published maps and institutional affiliations.

Copyright: (c) 2021 by the authors. Licensee MDPI, Basel, Switzerland. This article is an open access article distributed under the terms and conditions of the Creative Commons Attribution (CC BY) license (https:// creativecommons.org/licenses/by/ $4.0 /)$.

\begin{abstract}
Three new polyene compounds, talacyanols A-C (1-3), along with two known compounds, ramulosin (4) and eurothiocin A (5), were isolated from the marine fungus Talaromyces cyanescens derived from a seaweed Caulerpa sp. Structures of 1-5 were established by one-dimensional and twodimensional (1D/2D) NMR, HR-ESIMS, and the modified Mosher's methods, as well as comparison with previously reported literature data. All the compounds (1-5) were tested for their in vitro cytotoxic and anti-neuroinflammatory activities. Among them, 1 showed moderate cytotoxic activity against a panel of cancer cell lines (HCT-15, NUGC-3, NCI-H23, ACHN, PC-3, and MDA-MB231) with $\mathrm{GI}_{50}$ values ranging from 44.4 to $91.6 \mu \mathrm{M}$, whereas compounds 2 and 5 exhibited antineuroinflammatory effect without cytotoxicity against all the tested cell lines.
\end{abstract}

Keywords: Talaromyces cyanescens; marine-derived fungus; polyenes; cytotoxicity; anti-neuroinflammatory

\section{Introduction}

Despite developing new therapeutic agents is a long, intricate, and costly process, the discovery and development of the new drugs are urgently needed due to the increase in the annual number of deaths caused by cancer, cardiovascular, respiratory, and neurodegenerative diseases, as well as the emergence and rapid growth of multidrug resistant pathogenic microbes [1,2].

Epiphytic and endophytic fungi have been known as potential sources of biologically active compounds, which may both directly and indirectly be used as therapeutically active substances against a wide variety of diseases [3-5]. Among them, the fungal genus Talaromyces has been recognized to be the prolific producers of structurally diverse and pharmacologically active secondary metabolites [6]. A large proportion of compounds, including alkaloids [7], terpenoids [8], polyketides [9], lactones [10], and quinones [11] demonstrated various bioactivities such as anticancer [12], antimicrobial [9], and antioxidant activities [13].

Cancer and Alzheimer's disease are the top leading causes of death worldwide, and neuro-inflammation plays a crucial role in the pathogenesis of Alzheimer's disease [14,15]. 
Therefore, there is an urgent and continuous need to find new classes of anticancer and anti-neuroinflammatory drugs. As a part of our continuing studies for novel marine fungal agents with potent cytotoxic and anti-neuroinflammatory effects, we isolated three new compounds possessing a polyene skeleton, talacyanols $\mathrm{A}-\mathrm{C}(\mathbf{1}-3)$, and two known compounds ramulosin (4) and eurothiocin A (5) from the marine-derived fungus Talaromyces sp. 168ST-51.1 (Figure 1). In this paper, we describe the isolation and structure identification of the secondary metabolites $\mathbf{1 - 5}$ and their in vitro cytotoxic and anti-neuroinflammatory activities.

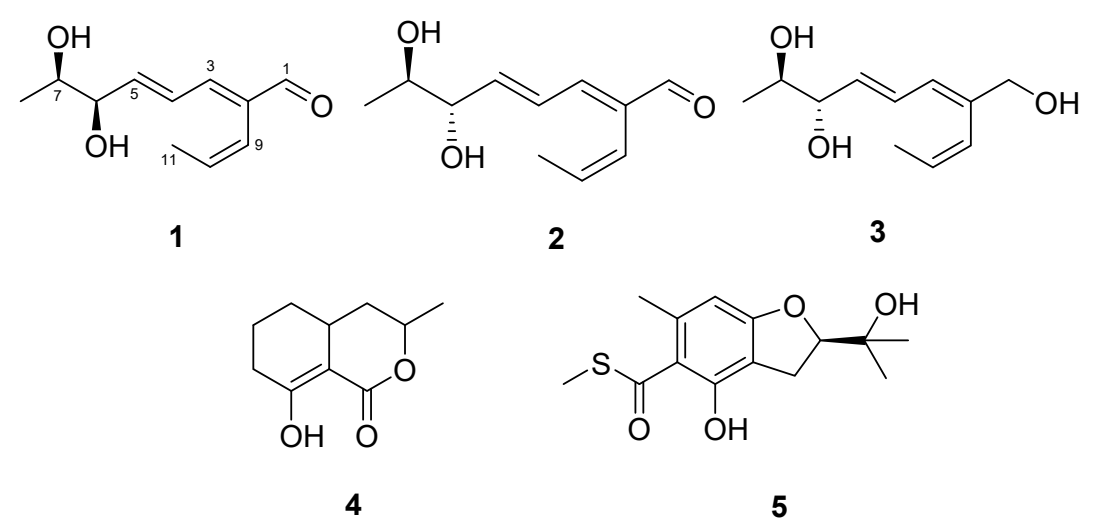

Figure 1. Structures of compounds 1-5 isolated from Talaromyces cyanescens.

\section{Results and Discussion}

\subsection{Structural Elucidation}

Compound 1 was isolated as a colorless oil with a molecular formula of $\mathrm{C}_{11} \mathrm{H}_{16} \mathrm{O}_{3}$, which was established from an HRESIMS peak at $m / z 219.1002[\mathrm{M}+\mathrm{Na}]^{+}$(calcd. for $\mathrm{C}_{11} \mathrm{H}_{16} \mathrm{O}_{3} \mathrm{Na}^{+}$, 219.0992). The ${ }^{1} \mathrm{H}$ NMR spectrum displayed signals of an aldehydic proton at $\delta_{\mathrm{H}} 9.46(\mathrm{H}-1)$, five olefinic protons at $\delta_{\mathrm{H}} 5.93-7.13$, two oxymethine protons at $\delta_{\mathrm{H}} 3.72$ $(\mathrm{H}-7)$ and $4.09(\mathrm{H}-6)$, and two methyl groups at $\delta_{\mathrm{H}} 1.14\left(\mathrm{H}_{3}-8\right)$ and $1.54\left(\mathrm{H}_{3}-11\right)$ (Table 1$)$. The ${ }^{13} \mathrm{C}$ NMR data exhibited the presence of eleven resonances, which were assigned for an aldehyde group at $\delta_{\mathrm{C}} 196.0$ (C-1), five protonated olefinic carbons at $\delta_{\mathrm{C}} 150.2(\mathrm{C}-3), 146.0$ (C-5), 132.5 (C-10), 128.8 (C-4), and 122.0 (C-9), a sp ${ }^{2}$ quaternary carbon at $\delta_{\mathrm{C}} 139.1(\mathrm{C}-2)$, two oxygenated methines at $\delta_{\mathrm{C}} 77.0$ (C-6), 71.4 (C-7), and two methyls at $\delta_{\mathrm{C}} 18.7(\mathrm{C}-8), 15.7$ (C-11) (Table 1). The above data suggested that 1 possesses an acyclic skeleton with an aldehyde and three pairs of $\mathrm{sp}^{2}$ carbons, accounting for all four degrees of unsaturation in accordance with its molecular formula.

Detailed analysis of ${ }^{1} \mathrm{H}_{-}{ }^{1} \mathrm{H}$ COSY correlations determined the partial structures of 1 including two distinct spin systems from $\mathrm{H}-3\left(\delta_{\mathrm{H}} 7.13\right)$ to $\mathrm{H}_{3}-8\left(\delta_{\mathrm{H}} 1.14\right)$, and from $\mathrm{H}-9$ $\left(\delta_{\mathrm{H}} 5.98\right)$ to $\mathrm{H}_{3}-11\left(\delta_{\mathrm{H}} 1.54\right)$. Furthermore, the linkages between the partial structures were identified on the basis of the HMBC spectrum. The HMBC correlations of H-1 $\left(\delta_{\mathrm{H}} 9.46\right)$, $\mathrm{H}-4\left(\delta_{\mathrm{H}} 6.66\right)$, and $\mathrm{H}-10\left(\delta_{\mathrm{H}} 5.92\right)$ to $\mathrm{C}-2\left(\delta_{\mathrm{C}} 139.1\right)$, and those of H-3, H-9 to C-1 $\left(\delta_{\mathrm{C}} 196.0\right)$ indicated that three parts of the compound were assembled via $\mathrm{C}-\mathrm{C}$ bonds from $\mathrm{C}-2$ to $\mathrm{C}-1$, C-3, and C-9. Thus, the planar structure of $\mathbf{1}$ was determined as shown in Figure 1. The geometries of the $\Delta^{2,4,9}$-double bonds could be interpreted as $2 E, 4 E$, and $9 \mathrm{Z}$ based on their ${ }^{3} J_{\mathrm{H}, \mathrm{H}}$ coupling constants of $\mathrm{H}-4 / \mathrm{H}-5(J=15.3 \mathrm{~Hz})$ and $\mathrm{H}-9 / \mathrm{H}-10(\mathrm{~J}=11.8 \mathrm{~Hz})$, as well as the strong NOESY correlations of $\mathrm{H}-3 / \mathrm{H}-1, \mathrm{H}-3 / \mathrm{H}-5$, and $\mathrm{H}-4 / \mathrm{H}_{3}-11$ (Figure 2).

The absolute configurations of four possible stereoisomers of the secondary 1,2-diols could be unambiguously determined using the modified Mosher's method (Figure 3A) by comparing the ${ }^{1} \mathrm{H}$ NMR data $\left(\Delta \delta_{\mathrm{S}-\mathrm{R}}\right)$ of their corresponding bis- $(S)$ - and - $(R)$-MTPA ( $\alpha$-methoxy- $\alpha$-trifluoromethylphenylacetic acid) esters (Figure 3B) $[16,17]$. Therefore, compound 1 was treated with $R$ - and $S$ - $\alpha$-methoxy- $\alpha$-(trifluoromethyl) phenylacetyl chloride (MTPA-Cl) to give bis-S- and -R-MTPA esters (1a and $\mathbf{1 b})$, respectively. As a result, the $\Delta \delta_{S-R}$ values of $\mathbf{1 a}$ and $\mathbf{1 b}$ were interpreted, which were consistent with syn-1,2-diols (Figure $3 \mathrm{~A}$ ) and the absolute configurations of the stereogenic centers were determined as 
$6 R$ and $7 R$. Thus, the structure of $\mathbf{1}$ was determined as $(2 E, 4 E, 6 R, 7 R)-6,7-$ dihydroxy-2-((Z)prop-1-en-1-yl)octa-2,4-dienal and named talacyanol A.

Table 1. ${ }^{1} \mathrm{H}$ and ${ }^{13} \mathrm{C}$ NMR data for $\mathbf{1 - 3}$ at $600 \mathrm{MHz}$ and $150 \mathrm{MHz}$ in $\mathrm{CD}_{3} \mathrm{OD}(\delta$ in ppm, $J$ in $\mathrm{Hz}$ ), respectively.

\begin{tabular}{|c|c|c|c|c|c|c|}
\hline \multirow{2}{*}{ Position } & \multicolumn{2}{|l|}{1} & \multicolumn{2}{|l|}{2} & \multicolumn{2}{|l|}{3} \\
\hline & $\delta_{\mathrm{H}}(J$ in $\mathrm{Hz})$ & $\delta_{\mathrm{C}}$ & $\delta_{\mathbf{H}}(J$ in $\mathbf{H z})$ & $\delta_{\mathrm{C}}$ & $\delta_{\mathrm{H}}(J$ in $\mathrm{Hz})$ & $\delta_{\mathrm{C}}$ \\
\hline 1 & $9.46, \mathrm{~s}$ & 196.0 & $9.46, \mathrm{~s}$ & 196.0 & $4.05, \mathrm{~s}$ & 66.4 \\
\hline 2 & & 139.1 & & 139.1 & & 139.8 \\
\hline 3 & $7.13(\mathrm{~d}, 11.2)$ & 150.2 & $7.13(\mathrm{~d}, 11.2)$ & 150.3 & $6.20(\mathrm{~d}, 11.0)$ & 126.6 \\
\hline 4 & $6.66(\mathrm{dd}, 11.3,15.3)$ & 128.8 & $6.63(\mathrm{dd}, 11.2,15.3)$ & 128.6 & $6.33(\mathrm{dd}, 11.0,15.3)$ & 130.7 \\
\hline 5 & $6.44(\mathrm{dd}, 5.6,15.3)$ & 146.0 & $6.49(\mathrm{dd}, 5.6,15.3)$ & 146.3 & $5.80(\mathrm{dd}, 7.0,15.4)$ & 134.1 \\
\hline 6 & $4.09(\mathrm{t}, 5.5)$ & 77.0 & $4.07(t, 5.4)$ & 77.0 & $3.93(t, 5.5)$ & 77.7 \\
\hline 7 & $3.72, \mathrm{~m}$ & 71.4 & $3.71, \mathrm{~m}$ & 71.5 & $3.67, \mathrm{~m}$ & 71.7 \\
\hline 8 & $1.14(\mathrm{~d}, 6.4)$ & 18.7 & $1.17(\mathrm{dd}, 1.0,6.4)$ & 18.9 & $1.13(\mathrm{~d}, 6.4)$ & 18.6 \\
\hline 9 & $5.98(\mathrm{~d}, 11.8)$ & 122.0 & $5.98(\mathrm{~d}, 11.8)$ & 122.0 & $5.90(\mathrm{~d}, 11.5)$ & 127.1 \\
\hline 10 & $5.92, \mathrm{~m}$ & 132.5 & $5.92, \mathrm{~m}$ & 132.4 & $5.75, \mathrm{~m}$ & 129.9 \\
\hline 11 & $1.54(\mathrm{~d}, 6.6)$ & 15.7 & $1.54(\mathrm{~d}, 6.6)$ & 15.7 & $1.61(\mathrm{dd}, 1.8,6.9)$ & 15.4 \\
\hline
\end{tabular}

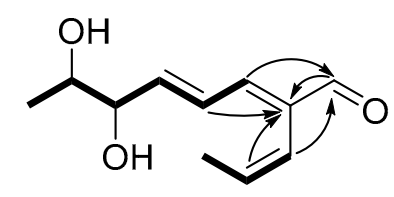

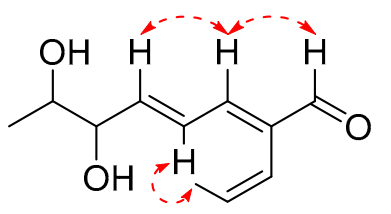

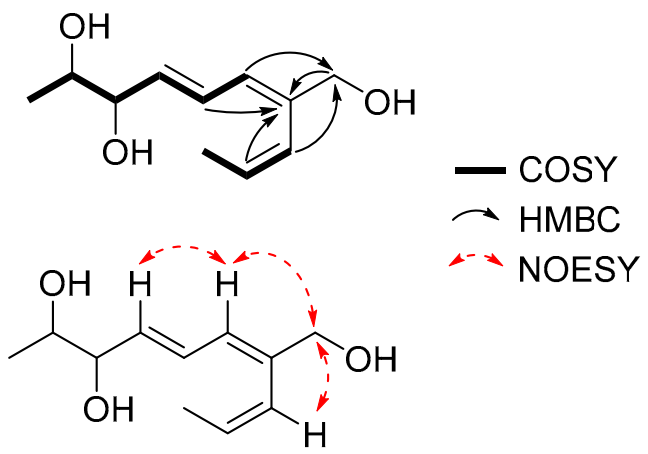

Figure 2. Key COSY, HMBC, and NOESY correlations for compounds 1-3.

(A)

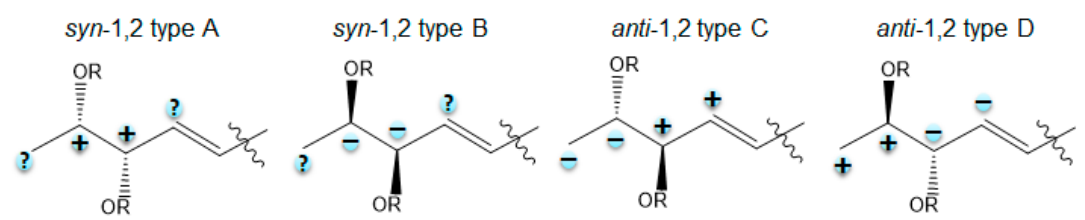

(B)

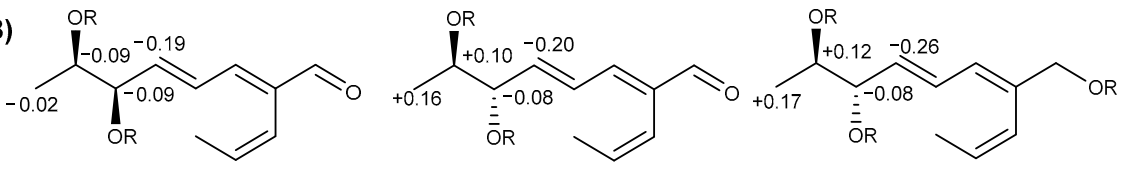

1a $\mathrm{R}=(S)-M T P A$ $1 \mathrm{~b} \mathrm{R}=(R)-\mathrm{MTPA}$

2a $\mathrm{R}=(S)-M T P A$ 2b R $=(R)$-MTPA

3a $\mathrm{R}=(S)$-MTPA $3 \mathrm{~b} \mathrm{R}=(R)$-MTPA

Figure 3. (A) Sign distribution $\left(\Delta \delta_{S}-{ }_{R}\right)$ of bis-MTPA esters of the four possible stereoisomers of 1,2-diols [16]; (B) $\Delta \delta_{S}-\mathrm{R}$ values of $\mathbf{1 a}-\mathbf{3 b}$ in CD3OD.

Compound 2 was isolated as a colorless oil with the same molecular formula of $\mathrm{C}_{11} \mathrm{H}_{16} \mathrm{O}_{3}$ to that of $\mathbf{1}$, which was established from an HRESIMS ion peak at $m / z 219.1003$ $[\mathrm{M}+\mathrm{Na}]^{+}$(calcd. for $\mathrm{C}_{11} \mathrm{H}_{16} \mathrm{O}_{3} \mathrm{Na}^{+}$, 219.0992). The one-dimensionial (1D) and twodimensional (2D) NMR data of $\mathbf{2}$ were almost identical to those of $\mathbf{1}$. By detailed analysis of NMR data, the planar structure of $\mathbf{2}$ was determined to be the same as that of $\mathbf{1}$ including the geometries of the double bounds (Figure 1). The only difference between 1 and 2 was the absolute stereochemistry of the secondary 1,2-diols at C-6 and C-7 according to their ${ }^{1} \mathrm{H}$ NMR data in $\mathrm{CDCl}_{3}\left(\delta_{\mathrm{H}-6} 4.28\right.$ and $\delta_{\mathrm{H}-7} 3.96$ for $1 ; \delta_{\mathrm{H}-6} 4.04$ and $\delta_{\mathrm{H}-7} 3.72$ for 2, 
Figure S23) and optical rotation values $[\alpha]_{\mathrm{D}}^{25}+76.6(c 0.2, \mathrm{MeOH})$ for $\mathbf{1} ;[\alpha]_{\mathrm{D}}^{25}-15(c$ 0.2, $\mathrm{MeOH}$ ) for 2). By comparing ${ }^{1} \mathrm{H}$ NMR data of bis-S- and -R-MTPA esters of 2, the absolute configurations at C-6 and C-7 were assigned as $6 S$ and $7 R$ (Figure 3B), and the structure of

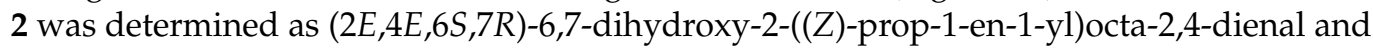
named talacyanol B.

Compound 3 was obtained as a colorless oil with a molecular formula of $\mathrm{C}_{11} \mathrm{H}_{18} \mathrm{O}_{3}$ based on its HRESIMS data $m / z 221.1155[\mathrm{M}+\mathrm{Na}]^{+}$(calcd for 221.1148, $\mathrm{C}_{11} \mathrm{H}_{18} \mathrm{O}_{3} \mathrm{Na}^{+}$). The ${ }^{1} \mathrm{H}$ NMR spectrum of $\mathbf{3}$ was quite similar to that of $\mathbf{2}$, the only difference lies in the chemical shift of the singlet proton $\mathrm{H}-1\left(\delta_{\mathrm{H}} 9.46\right.$ in $2, \delta_{\mathrm{H}} 4.05$ in 3), indicating that the aldehyde group at C-1 in 2 was replaced by a hydroxy group in 3 . Thus, the planar structure of 3 was elucidated as shown in Figure 1 based on its 1D and 2D NMR data.

A literature search revealed that the planar structure of $\mathbf{3}$ was similar to pinophol A, which was isolated from a plant endophytic fungus Talaromyces pinophilus by Zhao et al. [18]. However, the absolute configurations at C-6 and C-7 of pinophol A had not been determined yet and their relative configurations were reported as syn-1,2-diols $(6 R, 7 R$ or $6 S, 7 S)$. Comparison of their optical rotation values $\left([\alpha]_{\mathrm{D}}^{25}-10(c 0.2, \mathrm{MeOH})\right.$ for 3 and $[\alpha]_{\mathrm{D}}^{26}+32.6(c 0.1, \mathrm{MeOH})$ for pinophol A) and ${ }^{1} \mathrm{H}$ NMR data in $\mathrm{CDCl}_{3}$ of 3 and pinophol $\mathrm{A}\left(\delta_{\mathrm{H}-6} 4.12\right.$ and $\delta_{\mathrm{H}-7} 3.88$ for 3 and $\delta_{\mathrm{H}-6} 3.87$ and $\delta_{\mathrm{H}-7} 3.63$ for pinophol A, Figure S22) suggested that they could be a pair of diastereomers. By analyzing ${ }^{1} \mathrm{H}$ NMR data of tri-Sand -R-MTPA esters of 3, the absolute configurations of C-6 and C-7 were determined as $6 S$ and $7 R$ (Figure $3 \mathrm{~B}$ ). Thus, the structure of $\mathbf{3}$ was determined as a new derivative of pinophol A, (2E,4E,6S,7R)-2-((Z)-prop-1-en-1-yl)octa-2,4-diene-1,6,7-triol, and named talacyanol C.

Aliphatic aldehydes are easily reduced to the corresponding alcohols in high yield by heterogeneous catalytic hydrogenation. To verify whether compound 3 is a true natural product or an artifact arising from compound 2 by reduction of aldehyde during the extraction process with ethyl acetate, we cultured the strain again and the culture broth was extracted successively with dichloromethane and n-butanol. Compound 3 was found in the butanol extract with a detectable concentration (Figures S31 and S32). Therefore, it could be concluded that 3 is a true natural substance.

The structures of the known compounds were identified as ramulosin (4), and eurothiocin A (5) by comparison of their spectroscopic data with those reported in the literature [19-21].

\subsection{Bioactivities}

Over the past few decades, emerging evidence has shown that many marine natural products, such as cytarabine, eribulin mesylate, brentuximab vedotin, and trabectidine exhibit beneficial effects in the prevention and treatment of cancer [22]. Furthermore, acyclic polyene polyols are a wide group of polyketides, and many of them display cytotoxicity against various cancer cell lines $[17,23]$. Therefore, compounds $\mathbf{1}-\mathbf{5}$ were screened for in vitro cytotoxicity against six different cancer cell lines (stomach NUGC-3, colon HCT-15, lung NCI-H23, breast MDA-MB-231, prostate PC-3, and renal ACHN), the most common cancers in Korea [24]. Notably, compound 1 displayed moderate cytotoxicity against all the cancer cell lines with $\mathrm{GI}_{50}$ values ranging from 44.4 to $91.8 \mu \mathrm{M}$ (Table 2).

Table 2. Growth inhibition $\left(\mathrm{GI}_{50}, \mu \mathrm{M}\right)$ values of $\mathbf{1}$ against human tumor cell lines.

\begin{tabular}{ccc}
\hline Cell Line & GI $_{\mathbf{5 0}}, \boldsymbol{\mu M}$ & ADR $^{\mathbf{a}}$ \\
\hline HCT-15 & 64.3 & $<0.5$ \\
NUGC-3 & 62.2 & $<0.5$ \\
NCI-H23 & 70.9 & $<0.5$ \\
ACHN & 44.4 & $<0.5$ \\
PC-3 & 54.1 & $<0.5$ \\
MDA-MB-231 & 91.8 & $<0.5$ \\
\hline
\end{tabular}

$\mathrm{GI}_{50}$ values are the concentration corresponding to $50 \%$ growth inhibition. ${ }^{a}$ ADR, adriamycin as standard. 
Compounds 1-5 were also tested for their inhibitory effects on the production of nitric oxide (NO) in lipopolysaccharide (LPS)-stimulated BV-2 microglial cells. The cells were initially treated with a high concentration $(200 \mu \mathrm{M})$ of each compound and LPS $(200 \mathrm{ng} / \mathrm{mL})$ to screen their inhibitory effect on NO production. All the compounds showed weak or strong inhibitory effects on NO production (Figure S33), and compounds $\mathbf{2}$ and $\mathbf{5}$ showed the most potent anti-inflammatory activity. Therefore, talacyanol B (2) and eurothiocin A (5) were selected for further studies to investigate NO production in BV-2 cells and LPS-induced expression levels of cyclooxygenase-2 (COX-2) and inducible nitric oxide synthase (iNOS) proteins by Western blot analysis. As shown in Figure 4A,B, the NO production and expression levels of COX-2 and iNOS proteins were suppressed by both 2 and 5 in a dose-related fashion at the concentrations of 50,100, and $200 \mu \mathrm{M}$.
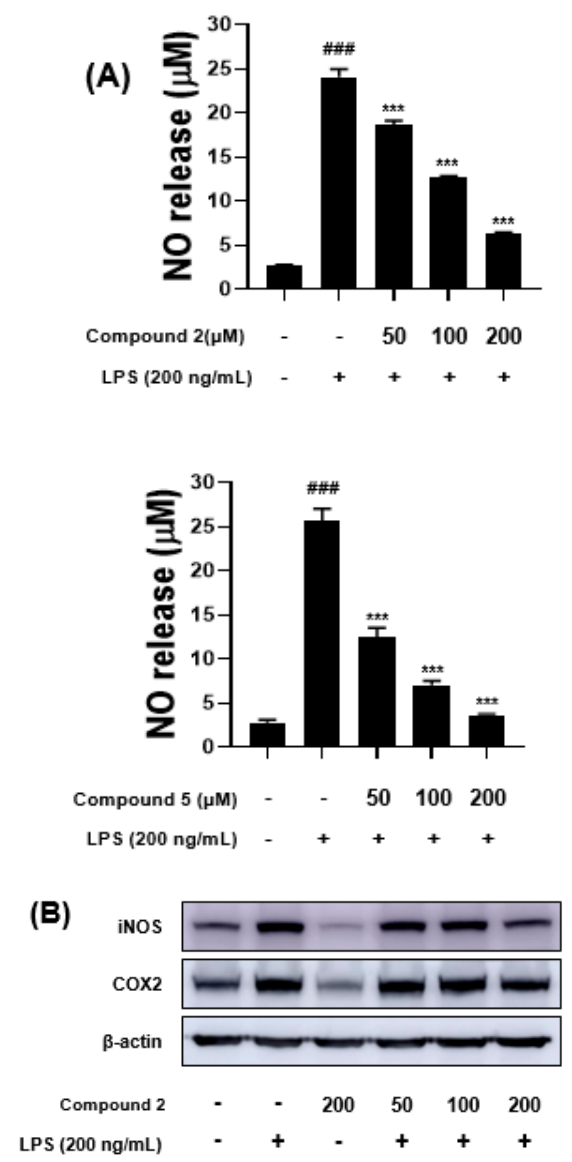
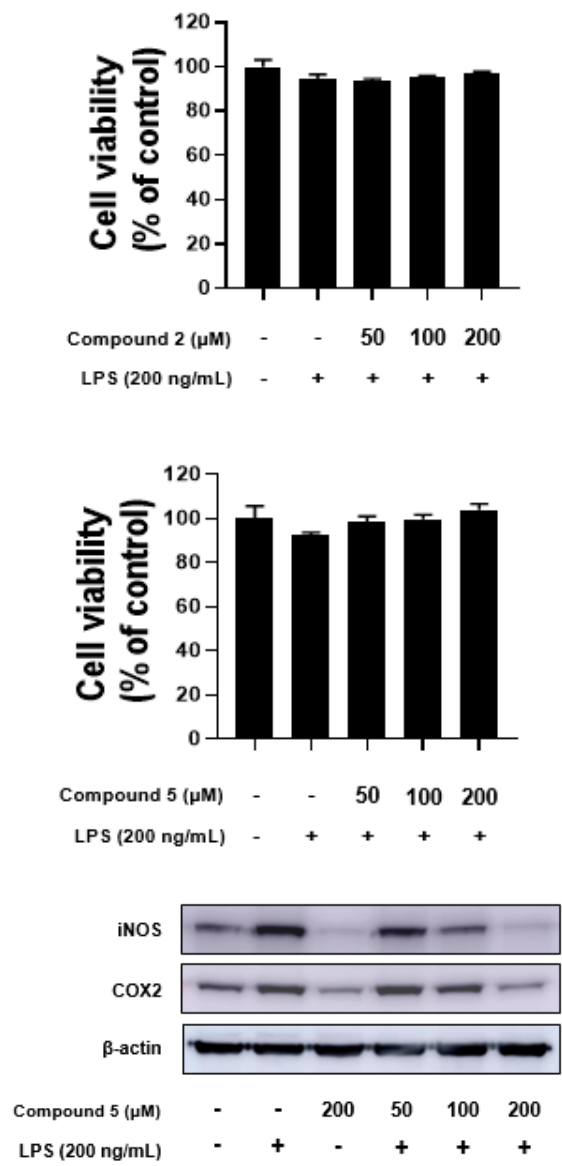

Figure 4. (A) The measurements of nitrite levels in the culture media were conducted using the Griess reaction. The release of NO was measured with indomethacin as a positive control (Figure S30). Cell viability was tested using the MTT (3-(4,5-dimetylthiazol-2-yl)-2,5-diphenyltetrazol bromide) assay. Results are shown as the percentage of control samples; (B) Inhibition of inducible nitric oxide synthase (iNOS) and cyclooxygenase-2 (COX-2) protein and mRNA expression by compounds 2 and 5 in lipopolysaccharide (LPS)-stimulated BV-2 cells. The data (B) is expressed as the relative signal intensity for two independent experiments. Values are the mean \pm standard error. ${ }^{\# \#} p<0.001$, vs. control group and ${ }^{* * *} p<0.001$ vs. LPS-treated group.

\section{Experimental Methods}

\subsection{General Experimental Procedures}

The $1 \mathrm{D}\left({ }^{1} \mathrm{H}\right.$ and $\left.{ }^{13} \mathrm{C}\right)$ and $2 \mathrm{D}(\mathrm{COSY}, \mathrm{HSQC}, \mathrm{HMBC}$, and NOESY) NMR spectra were acquired by a Bruker $600 \mathrm{MHz}$ spectrometer (Bruker BioSpin $\mathrm{GmbH}$, Rheinstetten, Germany). Specific optical rotations were obtained in methanol at $25^{\circ} \mathrm{C}$ on a Rudolph Research Analytical (Autopol III) polarimeter (Rudolph Research Analytical, Hackettstown, NJ, USA). UV-visible spectra were acquired by a Shimadzu UV-1650PC spectrophotometer in $1 \mathrm{~mm}$ 
quartz cells (Shimadzu Corporation, Kyoto, Japan). IR spectra were collected on a JASCO FT/IR-4100 spectrophotometer (JASCO Corporation, Tokyo, Japan). High-resolution ESIMS were recorded on a hybrid ion-trap time-of-flight mass spectrometer (Shimadzu LC/MS-IT-TOF). HPLC was conducted using a semi-prep ODS column (YMC-Triart $\mathrm{C}_{18}$, $250 \times 10 \mathrm{~mm}$ i.d, $5 \mu \mathrm{m}$ ) and an analytical ODS column (YMC-Triart $\mathrm{C}_{18}, 250 \times 4.6 \mathrm{~mm}$ i.d, $5 \mu \mathrm{m})$ (YMC Corporation, Kyoto, Japan). All the reagents were purchased from SigmaAldrich (Merck KGaA, Darmstadt, Germany), and the organic solvents and water were distilled prior to use.

\subsection{Fungal Material and Fermentation}

The fungal strain 168ST-51.1 was isolated from the seaweed Caulerpa sp. collected in Son Tra peninsular, Da Nang, Vietnam in August 2016. The fungus was identified as Talaromyces cyanescens Stchigel \& Guarro on the basis of DNA amplification and ITS gene sequencing (GenBank accession number MK 072976.1). The voucher of this strain is currently deposited in the Microbial Culture Collection, KIOST, with the name of Talaromyces sp. 168ST-51.1 under the curatorship of Hee Jae Shin.

The seed and mass cultures were performed in Bennett's medium (1\% glucose, $0.2 \%$ tryptone, $0.1 \%$ yeast extract, $0.1 \%$ beef extract, $0.5 \%$ glycerol, sea salts $32 \mathrm{~g} / \mathrm{L}$, and agar $17 \mathrm{~g} / \mathrm{L}$ for agar medium). The fungus was initially cultured on Bennett's agar medium in a Petri dish for 7 days. The actively grown mycelium was transferred aseptically into a $500 \mathrm{~mL}$ conical flask containing $300 \mathrm{~mL}$ of Bennett's broth medium and incubated on a rotary shaker $(140 \mathrm{rpm})$ at $28{ }^{\circ} \mathrm{C}$ for 4 days. An aliquot $(0.1 \% v / v)$ from the seed culture was inoculated into twenty $2 \mathrm{~L}$ flasks each containing $1 \mathrm{~L}$ of the medium and grown under the same conditions as described for the seed culture for 7 days, and then harvested.

\subsection{Extraction and Isolation of Metabolites}

After cultivation, the culture broth was extracted with ethyl acetate $(20 \mathrm{~L} \times 2$ times). The organic layer was evaporated under vacuum at $37^{\circ} \mathrm{C}$ to yield a crude extract $(3.0 \mathrm{~g})$. Afterwards, the crude extract was separated into fifteen fractions (Fr. 1 to Fr. 15) by vacuum liquid chromatography on a flash ODS column $(20 \mathrm{~cm} \times 4.5 \mathrm{~cm})$, which was stepwise eluted with $3 \times 250 \mathrm{~mL}$ each of $20 \%, 40 \%, 60 \%, 80 \% \mathrm{MeOH}$ in $\mathrm{H}_{2} \mathrm{O}$, and $100 \% \mathrm{MeOH}$. Fraction 4 was purified by an analytical RP-HPLC (YMC-Pack-ODS-A, $250 \times 4.6 \mathrm{~mm}$ i.d, $5 \mu \mathrm{m})$ using an isocratic condition with $14 \% \mathrm{ACN}$ in $\mathrm{H}_{2} \mathrm{O}$ at a flow rate of $1 \mathrm{~mL} / \mathrm{min}$ to afford compound $3\left(3.0 \mathrm{mg}, t_{\mathrm{R}}=15 \mathrm{~min}\right)$. Fraction 5 was applied to a semi-preparative RPHPLC (YMC-Pack-ODS-A, $250 \times 10 \mathrm{~mm}$ i.d, $5 \mu \mathrm{m}$, flow rate $2.0 \mathrm{~mL} / \mathrm{min}$ ) using an isocratic elution with $14 \% \mathrm{ACN}$ in $\mathrm{H}_{2} \mathrm{O}$ to yield compounds $2\left(20.0 \mathrm{mg}\right.$, $\left.t_{\mathrm{R}}=38 \mathrm{~min}\right)$ and $\mathbf{1}(5.0 \mathrm{mg}$, $\left.t_{R}=42 \mathrm{~min}\right)$. Fraction 9 was recrystallized from methanol to give compound $4(10.0 \mathrm{mg})$ as yellow needles. Finally, compound $5(4.0 \mathrm{mg})$ was purified from fraction 10 using a semipreparative RP-HPLC (YMC-Pack-ODS-A, $250 \times 10 \mathrm{~mm}$ i.d, $5 \mu \mathrm{m}$, flow rate $2.0 \mathrm{~mL} / \mathrm{min}$ ) with an isocratic elution of $37 \% \mathrm{ACN}$ in $\mathrm{H}_{2} \mathrm{O}$ for $46 \mathrm{~min}$. All the purification procedure was repeated 2 times to yield sufficient amounts of $\mathbf{1}-\mathbf{5}$ for structure determination and bioassays.

\subsubsection{Talacyanol A (1)}

Colorless oil, $[\alpha]_{\mathrm{D}}^{25}+76.6\left(c\right.$ 0.2, MeOH). UV (MeOH) $\lambda_{\max }(\log \varepsilon) 285$ (2.86), 232 (2.38) $\mathrm{nm}$; IR (MeOH) $v_{\max } 3392$ (br), 2975, 2933, 1671, $1632 \mathrm{~cm}^{-1}$; HRESIMS $m / z 219.1002$ $[\mathrm{M}+\mathrm{Na}]^{+}$(calcd for 219.0992, $\left.\mathrm{C}_{11} \mathrm{H}_{16} \mathrm{O}_{3} \mathrm{Na}^{+}\right) ;{ }^{1} \mathrm{H} \mathrm{NMR}\left(\mathrm{CD}_{3} \mathrm{OD}, 600 \mathrm{MHz}\right)$ and ${ }^{13} \mathrm{C} \mathrm{NMR}$ $\left(\mathrm{CD}_{3} \mathrm{OD}, 150 \mathrm{MHz}\right)$ see Table 1.

\subsubsection{Talacyanol B (2)}

Colorless oil, $[\alpha]_{\mathrm{D}}^{25}-15$ (c 0.2, MeOH). UV (MeOH) $\lambda_{\max }(\log \varepsilon) 285$ (2.86), 232 (2.38) $\mathrm{nm}$; IR (MeOH) $v_{\max } 3392$ (br), 2975, 2939, 1671, $1632 \mathrm{~cm}^{-1}$; HRESIMS $\mathrm{m} / z 219.1003$ $[\mathrm{M}+\mathrm{Na}]^{+}$(calcd for 219.0992, $\left.\mathrm{C}_{11} \mathrm{H}_{16} \mathrm{O}_{3} \mathrm{Na}^{+}\right) ;{ }^{1} \mathrm{H} \mathrm{NMR}\left(\mathrm{CD}_{3} \mathrm{OD}, 600 \mathrm{MHz}\right)$ and ${ }^{13} \mathrm{C} \mathrm{NMR}$ $\left(\mathrm{CD}_{3} \mathrm{OD}, 150 \mathrm{MHz}\right)$ see Table 1. 


\subsubsection{Talacyanol C (3)}

Colorless oil, $[\alpha]_{\mathrm{D}}^{25}-10\left(\right.$ c 0.2, MeOH). UV (MeOH) $\lambda_{\max }(\log \varepsilon) 248$ (2.61), 204 (1.56) $\mathrm{nm}$; IR (MeOH) $v_{\max } 3335$ (br), 2971, 2943, $1056 \mathrm{~cm}^{-1}$; HRESIMS $m / z 221.1155[\mathrm{M}+\mathrm{Na}]^{+}$ (calcd for 221.1148, $\left.\mathrm{C}_{11} \mathrm{H}_{18} \mathrm{O}_{3} \mathrm{Na}^{+}\right) ;{ }^{1} \mathrm{H} \mathrm{NMR}\left(\mathrm{CD}_{3} \mathrm{OD}, 600 \mathrm{MHz}\right)$ and ${ }^{13} \mathrm{C} \mathrm{NMR}\left(\mathrm{CD}_{3} \mathrm{OD}\right.$, $150 \mathrm{MHz}$ ) see Table 1.

\subsection{MTPA Esterification of Compounds 1-3}

Compound 1 (1.0 $\mathrm{mg}$ for each) was dissolved in anhydrous pyridine $(200 \mu \mathrm{L})$, and then added dimethylaminopyridine (DMAP). Afterwards, $(R)$-MTPA-Cl $(20 \mu \mathrm{L})$ or $(S)$-MTPA-Cl $(20 \mu \mathrm{L})$ were introduced, and reaction mixture was stirred at ambient temperature for $30 \mathrm{~min}$, and then quenched with $\mathrm{MeOH}$. Each mixture ((a) $\mathbf{1}$ with $\mathbf{1 a}$ and (b) $\mathbf{1}$ with $\mathbf{1 b}$ ) was dried to dryness and purified by analytical reversed-phase HPLC to afford $\mathbf{1 a}$ and $\mathbf{1 b}$. $(R)$ - and (S)-MTPA esters of compounds $\mathbf{2}$ and $\mathbf{3}$ were prepared in the same procedure as described above for compound 1 . The $\Delta \delta_{S-R}$ values around the stereogenic centers of the MTPA esters were determined by ${ }^{1} \mathrm{H}, \mathrm{HSQC}$, and ${ }^{1} \mathrm{H}-{ }^{1} \mathrm{H}$ COSY NMR spectra.

\subsubsection{Bis-S-MTPA Ester (1a) of Talacyanol A (1)}

${ }^{1} \mathrm{H}$ NMR $\left(600 \mathrm{MHz}, \mathrm{CD}_{3} \mathrm{OD}\right) \delta 9.47(\mathrm{~s}, 1 \mathrm{H}), 7.39-7.51(\mathrm{~m}, 10 \mathrm{H}), 6.87(\mathrm{~d}, J=11.1,1 \mathrm{H})$, $6.54(\mathrm{dd}, J=11.7,14.9,1 \mathrm{H}), 6.04(\mathrm{dd}, J=6.3,15.4,1 \mathrm{H}), 5.86(\mathrm{~m}, 2 \mathrm{H}), 5.74(\mathrm{dd}, J=2.8,6.3$, $1 \mathrm{H}), 5.36(\mathrm{~m}, 1 \mathrm{H}), 3.46(\mathrm{~s}, 3 \mathrm{H}), 3.45(\mathrm{~s}, 3 \mathrm{H}), 1.40(\mathrm{~d}, J=5.1,3 \mathrm{H}), 1.28(\mathrm{~d}, J=6.5,3 \mathrm{H})$.

\subsubsection{Bis-R-MTPA Ester (1b) of Talacyanol A (1)}

${ }^{1} \mathrm{H}$ NMR $\left(600 \mathrm{MHz}, \mathrm{CD}_{3} \mathrm{OD}\right) \delta 9.47(\mathrm{~s}, 1 \mathrm{H}), 7.39-7.49(\mathrm{~m}, 10 \mathrm{H}), 7.02(\mathrm{~d}, J=11.2,1 \mathrm{H})$, $6.52(\mathrm{dd}, J=10.9,15.1,1 \mathrm{H}), 6.23(\mathrm{dd}, J=5.9,15.5,1 \mathrm{H}), 5.84(\mathrm{~m}, 2 \mathrm{H}), 5.83(\mathrm{~m}, 1 \mathrm{H}), 5.45(\mathrm{~m}$, $1 \mathrm{H}), 3.44(\mathrm{~s}, 3 \mathrm{H}), 3.43(\mathrm{~s}, 3 \mathrm{H}), 1.40(\mathrm{~d}, J=5.4,3 \mathrm{H}), 1.30(\mathrm{~d}, J=6.6,3 \mathrm{H})$.

\subsubsection{Bis-S-MTPA Ester (2a) of Talacyanol B (2)}

${ }^{1} \mathrm{H}$ NMR $\left(600 \mathrm{MHz}, \mathrm{CD}_{3} \mathrm{OD}\right) \delta 9.47(\mathrm{~s}, 1 \mathrm{H}), 7.32-7.49(\mathrm{~m}, 10 \mathrm{H}), 6.98(\mathrm{~d}, J=11.2,1 \mathrm{H})$, $6.51(\mathrm{dd}, J=11.0,15.4,1 \mathrm{H}), 6.12(\mathrm{dd}, J=6.9,15.4,1 \mathrm{H}), 5.88(\mathrm{~m}, 2 \mathrm{H}), 5.82(\mathrm{dd}, J=2.5,5.9$, $1 \mathrm{H}), 5.52(\mathrm{~m}, 1 \mathrm{H}), 3.47(\mathrm{~s}, 3 \mathrm{H}), 3.44(\mathrm{~s}, 3 \mathrm{H}), 1.47(\mathrm{~d}, J=5.2,3 \mathrm{H}), 1.35(\mathrm{~d}, J=6.6,3 \mathrm{H})$.

\subsubsection{Bis-R-MTPA Ester (2b) of Talacyanol B (2)}

${ }^{1} \mathrm{H}$ NMR $\left(600 \mathrm{MHz}, \mathrm{CD}_{3} \mathrm{OD}\right) \delta 9.49(\mathrm{~s}, 1 \mathrm{H}), 7.33-7.48(\mathrm{~m}, 10 \mathrm{H}), 7.08(\mathrm{~d}, J=11.1,1 \mathrm{H})$, $6.73(\mathrm{dd}, J=11.0,15.4,1 \mathrm{H}), 6.32(\mathrm{dd}, J=7.0,15.5,1 \mathrm{H}), 5.94(\mathrm{~m}, 2 \mathrm{H}), 5.90(\mathrm{dd}, J=2.7,6.8$, $1 \mathrm{H}), 5.42(\mathrm{~m}, 1 \mathrm{H}), 3.43(\mathrm{~s}, 3 \mathrm{H}), 3.41(\mathrm{~s}, 3 \mathrm{H}), 1.47(\mathrm{~d}, J=5.1,3 \mathrm{H}), 1.19(\mathrm{~d}, J=6.6,3 \mathrm{H})$.

\subsubsection{Tri-S-MTPA Ester (3a) of Talacyanol C (3)}

${ }^{1} \mathrm{H}$ NMR $\left(600 \mathrm{MHz}, \mathrm{CD}_{3} \mathrm{OD}\right) 7.28-7.51(\mathrm{~m}, 15 \mathrm{H}), 6.33(\mathrm{dd}, J=10.8,15.3,1 \mathrm{H}), 6.08(\mathrm{~d}$, $J=10.9,1 \mathrm{H}), 5.77(\mathrm{~m}, 2 \mathrm{H}), 5.65(\mathrm{dd}, J=2.2,7.6,1 \mathrm{H}), 5.47(\mathrm{dd}, J=7.58,15.3,1 \mathrm{H}), 5.44(\mathrm{~m}$, $1 \mathrm{H}), 4.88(\mathrm{~d}, J=10.3,1 \mathrm{H}), 4.82(\mathrm{~d}, J=14.0,1 \mathrm{H}), 3.52(\mathrm{~s}, 3 \mathrm{H}), 3.44(\mathrm{~s}, 3 \mathrm{H}), 3.44(\mathrm{~s}, 3 \mathrm{H}), 1.48(\mathrm{~d}$, $J=5.3,3 \mathrm{H}), 1.31(\mathrm{~d}, J=6.6,3 \mathrm{H})$.

\subsubsection{Tri-R-MTPA Ester (3b) of Talacyanol C (3)}

${ }^{1} \mathrm{H}$ NMR $\left(600 \mathrm{MHz}, \mathrm{CD}_{3} \mathrm{OD}\right) 7.32-7.50(\mathrm{~m}, 15 \mathrm{H}), 6.47(\mathrm{~m}, 1 \mathrm{H}), 6.15(\mathrm{~d}, J=10.9,1 \mathrm{H})$, $6.04(\mathrm{dd}, J=6.3,15.4,1 \mathrm{H}), 5.80(\mathrm{~m}, 2 \mathrm{H}), 5.73(\mathrm{~m}, 2 \mathrm{H}), 5.34(\mathrm{~m}, 1 \mathrm{H}), 4.91(\mathrm{~d}, J=12.8,1 \mathrm{H}), 4.80$ $(\mathrm{d}, J=12.8,1 \mathrm{H}), 3.51(\mathrm{~s}, 3 \mathrm{H}), 3.42(\mathrm{~s}, 3 \mathrm{H}), 3.39(\mathrm{~s}, 3 \mathrm{H}), 1.44(\mathrm{~d}, J=5.4,3 \mathrm{H}), 1.14(\mathrm{~d}, J=6.5$, $3 \mathrm{H})$.

\subsection{Cytotoxicity Test by SRB Assay and Anti-Neuroinflammatory Test}

The SRB cytotoxicity assay and anti-neuroinflammatory test for compounds $\mathbf{1 - 5}$ were performed as previously described $[25,26]$. 


\section{Conclusions}

Chemical examination of the ethyl acetate extract of the marine-derived fungus $\mathrm{Ta}$ laromyces cyanescens $168 \mathrm{ST}-51.1$ led to the isolation of three new compounds, talacyanol A-C (1-3), together with two known compounds 4 and 5 . The structures of the new compounds 1-3 were determined by the spectroscopic and modified Mosher's methods. The known compounds $\mathbf{4} \mathbf{- 5}$ were identified by comparing their spectroscopic data with those reported in literature. Talacyanol A (1) expressed in vitro cytotoxicity against various cancer cell lines. In contrast, talacyanol B (2) and eurothiocin A (5) showed anti-neuroinflammatory activity without cytotoxicity. The results demonstrated that the absolute configurations of the chiral centers may exert significant effects on biological activities of natural products. To the best of our knowledge, this is the first report on the cytotoxicity of compound $\mathbf{1}$ and the anti-neuroinflammatory effect of compounds $\mathbf{2}$ and $\mathbf{5}$.

Supplementary Materials: The following materials are available online, Figures S1-S23: HRESI-MS data, ${ }^{1} \mathrm{H}$ NMR, ${ }^{13} \mathrm{C}$ NMR, ${ }^{1} \mathrm{H}-{ }^{1} \mathrm{H}$ COSY, HSQC, HMBC, NOESY experimental spectra of compounds 1-3, Figures S24-S29: ${ }^{1} \mathrm{H}$ NMR spectra of $R$ - and S-MTPA esters of compounds 1-3.

Author Contributions: H.J.S. was the principal investigator, who proposed the ideas for the present work, managed and supervised the whole research work, prepared and corrected the manuscript, and contributed to the structure elucidation of the new and known compounds; C.V.A. achieved all experiments for compounds 1-5, including fermentation, isolation, and structure elucidation, and prepared the manuscript; P.T.H.T., H.-S.L., and B.-K.C. contributed to analyzing data; D.-Y.C., and D.-K.C. evaluated the anti-neuroinflammatory activity; J.S.K. performed the experiments related to cytotoxicity of 1-5. All authors have read and agreed to the published version of the manuscript.

Funding: This research was supported in part by the Korea Institute of Ocean Science and Technology (grant PE99852) and the Ministry of Oceans and Fisheries, Republic of Korea (grant PM59122).

Institutional Review Board Statement: Not applicable.

Informed Consent Statement: Not applicable.

Data Availability Statement: The Data presented in the article are available in the supplementary materials.

Acknowledgments: The authors express gratitude to Young Hye Kim, Korea Basic Science Institute, Ochang, Korea, for providing mass data. Authors would like to thank the Vietnam Government for allowing us to do marine microbial research.

Conflicts of Interest: The authors declare no conflict of interest.

Sample Availability: Samples of the compounds are available from the authors.

\section{References}

1. Klemm, E.J.; Wong, V.K.; Dougan, G. Emergence of dominant multidrug-resistant bacterial clades: Lessons from history and whole-genome sequencing. Proc. Natl. Acad. Sci. USA 2018, 115, 12872-12877. [CrossRef] [PubMed]

2. Mathers, C.; Stevens, G.; Hogan, D.; Mahanani, W.R.; Ho, J. Global and Regional Causes of Death: Patterns and Trends, $2000-2015$. In Disease Control Priorities: Improving Health and Reducing Poverty, 3rd ed.; Jamison, D.T., Gelband, H., Horton, S., Jha, P., Laxminarayan, R., Mock, C.N., Nugent, R., Eds.; The World Bank: Washington, DC, USA, 2017; Volume 9, pp. 69-104.

3. Newman, D.J.; Cragg, G.M. Natural products as sources of new drugs over the nearly four decades from $01 / 1981$ to $09 / 2019$. J. Nat. Prod. 2020, 83, 770-803. [CrossRef] [PubMed]

4. Malve, H. Exploring the ocean for new drug developments: Marine pharmacology. J. Pharm. Bioallied. Sci. 2016, 8, 83-91. [CrossRef]

5. Rateb, M.E.; Ebel, R. Secondary metabolites of fungi from marine habitats. Nat. Prod. Rep. 2011, 28, 290-344. [CrossRef] [PubMed]

6. Zhai, M.M.; Li, J.; Jiang, C.X.; Shi, Y.P.; Di, D.L.; Crews, P.; Wu, Q.X. The bioactive secondary metabolites from Talaromyces species. Nat. Prod. Bioprospect. 2016, 6, 1-24. [CrossRef] [PubMed]

7. Chen, S.; He, L.; Chen, D.; Cai, R.; Long, Y.; Lu, Y.; She, J. Talaramide A, an unusual alkaloid from the mangrove endophytic fungus Talaromyces sp. (HZ-YX1) as an inhibitor of mycobacterial PknG. New J. Chem. 2017, 41, 4273-4276. [CrossRef]

8. Meng, L.H.; Li, X.M.; Zhang, F.Z.; Wang, Y.N.; Wang, B.G. Talascortenes A-G, highly oxygenated diterpenoid acids from the sea-anemone-derived endozoic fungus Talaromyces scorteus AS-242. J. Nat. Prod. 2020, 83, 2528-2536. [CrossRef] [PubMed] 
9. Wu, B.; Ohlendorf, B.; Oesker, V.; Wiese, J.; Malien, S.; Schmaljohann, R.; Imhoff, J.F. Acetylcholinesterase inhibitors from a marine fungus Talaromyces sp. Strain LF458. Mar. Biotechnol. 2015, 17, 110-119. [CrossRef] [PubMed]

10. Küppers, L.; Ebrahim, W.; El-Neketi, M.; Özkaya, F.C.; Mándi, A.; Kurtán, T.; Orfali, R.S.; Müller, W.E.G.; Hartmann, R.; Lin, W.; et al. Lactones from the sponge-derived fungus Talaromyces rugulosus. Mar. Drugs 2017, 15, 359. [CrossRef] [PubMed]

11. Noinart, J.; Buttachon, S.; Dethoup, T.; Gales, L.; Pereira, J.A.; Urbatzka, R.; Freitas, S.; Lee, M.; Silva, A.M.S.; Pinto, M.M.M.; et al. A new ergosterol analog, a new bis-anthraquinone and anti-obesity activity of anthraquinones from the marine sponge-associated fungus Talaromyces stipitatus KUFA 0207. Mar. Drugs 2017, 15, 139. [CrossRef] [PubMed]

12. Li, H.; Huang, H.; Shao, C.; Huang, H.; Jiang, J.; Zhu, X.; Liu, Y.; Liu, L.; Lu, Y.; Li, M.; et al. Cytotoxic norsesquiterpene peroxides from the endophytic fungus Talaromyces flavus isolated from the mangrove plant Sonneratia apetala. J. Nat. Prod. 2011, 74, 1230-1235. [CrossRef] [PubMed]

13. Li, H.L.; Li, X.M.; Li, X.; Wang, C.Y.; Liu, H.; Kassack, M.U.; Meng, L.H.; Wang, B.G. Antioxidant hydroanthraquinones from the marine algal-derived endophytic fungus Talaromyces islandicus EN-501. J. Nat. Prod. 2017, 80, 162-168. [CrossRef] [PubMed]

14. WHO. The Top 10 Causes of Death. Available online: https://www.who.int/news-room/fact-sheets/detail/the-top-10-causesof-death (accessed on 9 December 2020).

15. Ardura-Fabregat, A.; Boddeke, E.W.G.M.; Boza-Serrano, A.; Brioschi, S.; Castro-Gomez, S.; Ceyzeriat, K.; Dansokho, C.; Dierkes, T.; Gelders, G.; Heneka, M.T.; et al. Targeting Neuroinflammation to Treat Alzheimer's Disease. CNS Drugs 2017, 31, 1057-1082. [CrossRef] [PubMed]

16. Freire, F.; Seco, J.M.; Quiñoá, E.; Riguera, R. Determining the absolute stereochemistry of secondary/ secondary diols by ${ }^{1} \mathrm{H}$ NMR: Basis and applications. J. Org. Chem. 2005, 70, 3778-3790. [CrossRef] [PubMed]

17. Bae, M.; Kim, H.; Shin, Y.; Kim, B.Y.; Lee, S.K.; Oh, K.-B.; Shin, J.; Oh, D.-C. Separacenes A-D, novel polyene polyols from the marine Actinomycete, Streptomyces sp. Mar. Drugs 2013, 11, 2882-2893. [CrossRef] [PubMed]

18. Zhao, W.T.; Shi, X.; Xian, P.J.; Feng, Z.; Yang, J.; Yang, X.L. A new fusicoccane diterpene and a new polyene from the plant endophytic fungus Talaromyces pinophilus and their antimicrobial activities. Nat. Prod. Res. 2019, 35, 1-7. [CrossRef] [PubMed]

19. Stodola, F.H.; Cabot, C.; Benjamin, C.R. Structure of ramulosin, a metabolic product of the fungus Pestalotia ramulosa. Biochem. J. 1964, 93, 92-97. [CrossRef] [PubMed]

20. Stierle, D.B.; Stierle, A.A.; Kunz, A. Dihydroramulosin from Botrytis sp. J. Nat. Prod. 1998, 61, 1277-1278. [CrossRef] [PubMed]

21. Liu, Z.; Xia, G.; Chen, S.; Liu, Y.; Li, H.; She, Z. Eurothiocin A and B, sulfur-containing benzofurans from a soft coral-derived fungus Eurotium rubrum SH-823. Mar. Drugs 2014, 12, 3669-3680. [CrossRef]

22. Khalifa, S.A.M.; Elias, N.; Farag, M.A.; Chen, L.; Saeed, A.; Hegazy, M.-E.F.; Moustafa, M.S.; Abd El-Wahed, A.; Al-Mousawi, S.M.; Musharraf, S.G.; et al. Marine Natural Products: A Source of Novel Anticancer Drugs. Mar. Drugs 2019, 17, 491. [CrossRef]

23. Smyrniotopoulos, V.; Firsova, D.; Fearnhead, H.; Grauso, L.; Mangoni, A.; Tasdemir, D. Density Functional Theory (DFT)-Aided Structure Elucidation of Linear Diterpenes from the Irish Brown Seaweed Bifurcaria bifurcata. Mar. Drugs 2021, 19, 42. [CrossRef] [PubMed]

24. Jung, K.W.; Won, Y.J.; Hong, S.; Kong, H.J.; Lee, E.S. Prediction of Cancer Incidence and Mortality in Korea. Cancer Res. Treat. 2020, 52, 351-358. [CrossRef] [PubMed]

25. Choi, B.K.; Jo, S.H.; Choi, D.K.; Trinh, P.T.H.; Lee, H.S.; Cao, V.A.; Van, T.T.T.; Shin, H.J. Anti-neuroinflammatory agent, restricticin $\mathrm{B}$, from the marine-derived fungus Penicillium janthinellum and its inhibitory activity on the no production in bv-2 microglia cells. Mar. Drugs 2020, 18, 465. [CrossRef] [PubMed]

26. Choi, B.-K.; Lee, H.-S.; Kang, J.S.; Shin, H.J. Dokdolipids A-C, hydroxylated rhamnolipids from the marine-derived Actinomycete Actinoalloteichus hymeniacidonis. Mar. Drugs 2019, 17, 237. [CrossRef] [PubMed] 